\title{
Within-population variation in mating system and parental care patterns in the Sanderling (Calidris alba) in northeast Greenland
}

Author(s): Jeroen Reneerkens, Pieter van Veelen, Marco van der Velde, Pieternella Luttikhuizen, and Theunis Piersma

Source: The Auk, 131(2):235-247. 2014.

Published By: The American Ornithologists' Union

DOI: http://dx.doi.org/10.1642/AUK-13-247.1

URL: http://www.bioone.org/doi/full/10.1642/AUK-13-247.1

BioOne (www.bioone.org) is a nonprofit, online aggregation of core research in the biological, ecological, and environmental sciences. BioOne provides a sustainable online platform for over 170 journals and books published by nonprofit societies, associations, museums, institutions, and presses.

Your use of this PDF, the BioOne Web site, and all posted and associated content indicates your acceptance of BioOne's Terms of Use, available at www.bioone.org/page/terms_of_use.

Usage of BioOne content is strictly limited to personal, educational, and non-commercial use. Commercial inquiries or rights and permissions requests should be directed to the individual publisher as copyright holder. 


\title{
Within-population variation in mating system and parental care patterns in the Sanderling (Calidris alba) in northeast Greenland
}

\author{
Jeroen Reneerkens, ${ }^{1 *}$ Pieter van Veelen, ${ }^{1 *}$ Marco van der Velde, ${ }^{1}$ Pieternella Luttikhuizen, ${ }^{2}$ and Theunis \\ Piersma ${ }^{1,2}$
}

1 Animal Ecology Group, Centre for Ecological and Evolutionary Studies, University of Groningen, Groningen, The Netherlands

${ }^{2}$ Department of Marine Ecology, NIOZ Royal Netherlands Institute for Sea Research, Den Burg, Texel, The Netherlands

* Both authors contributed equally. Corresponding author: j.w.h.reneerkens@rug.nl

Received January 8, 2014; Accepted January 9, 2014; Published March 26, 2014

\begin{abstract}
Sandpipers and allies (Scolopacidae) show an astounding diversity in mating and parental care strategies. Comparative studies have tried to interpret this variation in terms of phylogenetic constraints and ecological shaping factors. In such analyses, mating and parental care systems are necessarily discretely classified at the species level. The few available descriptive studies on breeding strategies of the Sanderling (Calidris alba) came to variable conclusions, which, in turn, were inconsistently used in these comparative studies. We provide empirical data on mating and parental care patterns in Sanderlings studied during six summers in northeast Greenland. In 135 clutches, we determined parental care from incubation profiles using temperature loggers and confirmed that both uniparental incubation by both sexes and biparental incubation ( 45 and 90 clutches, respectively) occurred. We used microsatellite-based parentage analyses to describe the degree of extrapair mating. In 48 completely assayed families, we found 6 cases of polygamy ( 4 cases of polyandry, 2 cases of polygyny) that involved both uniparental and biparental clutches. This implies substantial variation in the patterns of mating and parental care, defying categorical assignments even at the local level. We conclude that the classification of mating strategy and parental care pattern for the Sanderling has been rather coarse, and that comparative analyses have not taken the observed intrapopulation variability into account. Because sandpipers show such variable reproductive behavior, between and within species, more detailed descriptive studies using parentage analyses are required to revisit previous statements about the intensity of sexual selection, including sexual size dimorphism, in shorebirds. In view of the great variability, methods of comparison will need elaboration too.
\end{abstract}

Keywords: Calidris alba, extrapair paternity, incubation, mating system, microsatellite analysis, parentage, parental care, polyandry, polygyny, shorebirds

\section{Variation intra-population dans les patrons d'accouplement et de soins parentaux chez Calidris alba dans le nord-est du Groenland}

\section{RÉSUMÉ}

Les bécasseaux et leurs alliés (Scolopacidés) présentent une étonnante diversité dans les stratégies d'accouplement et de soins parentaux. Des études comparatives ont tenté d'interpréter cette variation en termes de contraintes phylogénétiques et de facteurs qui influent sur l'écologie. Dans ces analyses, les systèmes d'accouplement et de soins parentaux sont nécessairement classés de façon distincte au niveau spécifique. Les quelques études descriptives disponibles sur les stratégies de reproduction de Calidris alba sont arrivées à des conclusions variables, qui n'étaient pas utilisées uniformément dans ces études comparatives. Nous fournissons ici des données empiriques sur les patrons d'accouplement et de soins parentaux chez des bécasseaux étudiés durant six étés dans le nord-est du Groenland. Nous avons identifiés les soins parentaux dans 135 couvées à partir de profils d'incubation et en utilisant des enregistreurs de température. Nous avons confirmé que l'incubation monoparentale chez les deux sexes ainsi que l'incubation biparentale (45 et 90 couvées, respectivement) se produisaient. Nous avons utilisé des analyses de la filiation basées sur les microsatellites pour décrire le degré de copulation hors couple. Chez 48 familles complètement analysées, nous avons trouvé six cas de polygamie (quatre cas de polyandrie, deux cas de polygynie) qui impliquaient à la fois des couvées monoparentales et des couvées biparentales. Ceci implique une variation substantielle dans les patrons d'accouplement et de soins parentaux, défiant l'attribution de catégories même au niveau local. Nous concluons que la classification du système d'accouplement et des patrons de soins parentaux pour C. alba a été plutôt primaire, et que les analyses comparatives n'ont pas pris en compte la variabilité intra-population observée. Parce que les bécasseaux présentent un tel comportement reproduction variable entre et au sein des espèces, des études descriptives plus détaillées utilisant des analyses de filiation sont requises pour revisiter les conclusions précédentes 
sur l'intensité de la sélection sexuelle, dont le dimorphisme de taille sexuel, chez les oiseaux de rivage. Compte tenu de cette grande variabilité, les méthodes de comparaison devront aussi être élaborées.

Mots-clés: système d'accouplement, analyse des microsatellites, filiation, paternité hors couple, polyandrie, polygynie, oiseaux de rivage, Calidris alba, soins parentaux, incubation

\section{INTRODUCTION}

Animal breeding systems are defined by variation in mating systems and parental care patterns (Reynolds 1996). In birds, the diversity in these systems is large (e.g., Ligon 1999). Sandpipers and allies (Scolopacidae), especially, show great variation in their breeding systems (Pitelka et al. 1974, Piersma et al. 1996, Bennett and Owens 2002). This feature has made sandpipers a popular subject of phylogenetic comparative analyses of social evolution (Székely and Reynolds 1995, Reynolds and Székely 1997, Thomas and Székely 2005, Székely et al. 2007, Olson et al. 2009). The diversification of breeding systems in shorebirds has been suggested to be driven by multiple forces, such as parental investment and sexual selection (Emlen and Oring 1977, Reynolds 1996, Olson et al. 2009), ecological factors such as migration distance (Myers 1981, Reynolds and Székely 1997, Sandercock et al. 2000, Garcia-Peña et al. 2009), and local environmental conditions (e.g., timing of snowmelt, predation danger, and resource availability; Kosztolányi et al. 2006, Smith et al. 2010).

Within birds, the subfamily of sandpipers (Calidridinae) is particularly known for its high diversity in social mating and parental care systems (e.g., Pitelka et al. 1974). In some species, this variation exists not only between conspecific populations in different hemispheres, but also within breeding populations (Whitfield and Tomkovich 1996). Socially monogamous shorebirds generally have low rates of extrapair paternity (Wallander et al. 2001, Blomqvist et al. 2002a, 2002b), but the genetic mating systems of many other shorebirds remain rather poorly studied (Székely et al. 2007; but see, e.g., Dale et al. 1999, Küpper et al. 2004). Despite a paucity of descriptive information, mating system and parental care patterns of the Sanderling (Calidris alba), along with those of many other shorebird species, have repeatedly been assigned to categories in phylogenetic comparative analyses.

The few studies available have suggested considerable variation in breeding strategies among Sanderling populations. Parmelee (1970) and Parmelee and Payne (1973), working in the Canadian High Arctic, reported incubation by single parents of both sexes (i.e. uniparental incubation) on the basis of continuous 24-h nest surveillance of a single nest for 14 days and repeat visits to 9 other nests. Examining dissected ovaries from 2 incubating females collected on Bathurst Island, Canada, led Parmelee and Payne (1973) to infer that paired Sanderlings lay two clutches in rapid succession ("double-clutching"), with each adult incubating one clutch on its own. The next published study (Pienkowski and Green 1976) took place during one summer in northeast Greenland and was based on 8 nests, including a single 24-h nest-observation session, and suggested that biparental incubation predominated. Observing 22 nesting attempts during two summers on Taimyr Peninsula, central north Siberia, Tomkovich and Soloviev (2001) suggested the occurrence of both uniparental (82\%) and biparental (18\%) incubation. A review of 11 comparative studies of shorebirds that included the Sanderling as a case showed remarkable inconsistency in the classifications of mating systems and parental care patterns (Table 1). Note that although these comparative studies all referred to the descriptive accounts by Parmelee and Payne (1973) and/or Pienkowski and Green (1976), whose conclusions were contradictory, none referred to the study by Tomkovich and Soloviev (2001). As an exception, Figuerola (1999) chose not to incorporate species with poorly known breeding biology, which in his opinion included the Sanderling.

Here, we provide a detailed description of breedingsystem variation in Sanderlings in northeast Greenland, based on 417 field days during six summers. Observation methods included the use of temperature-data loggers at nests and parentage analyses using microsatellite markers. Our results show substantial variation in mating patterns and the division of incubation duties in this single population.

\section{METHODS}

\section{General Information}

Sanderlings are long-distance migrating shorebirds breeding in High Arctic Canada, Greenland, and northern Siberia (Piersma et al. 1996, Lappo et al. 2012). Breeding populations from Greenland spend the nonbreeding season at coastal beaches and intertidal flats from northwest Europe to southern Africa and arrive on the breeding grounds from late May onward (Reneerkens et al. 2009). Pairs are usually formed very soon after arrival at the breeding grounds (i.e. it is rare to find single birds in early June; J. Reneerkens personal observation). Males perform display flights; often, two or three males can be seen in aerial pursuit of a female. After pair formation until clutch completion, a male intensively guards his female by staying in her close vicinity during foraging in the surroundings of the nest location and continually making 
TABLE 1. Previous characterizations of the social breeding system of Sanderlings $(M O=$ monogamy, $P A=$ polyandry, $P O=$ polygamy, and SPA = serial polyandry).

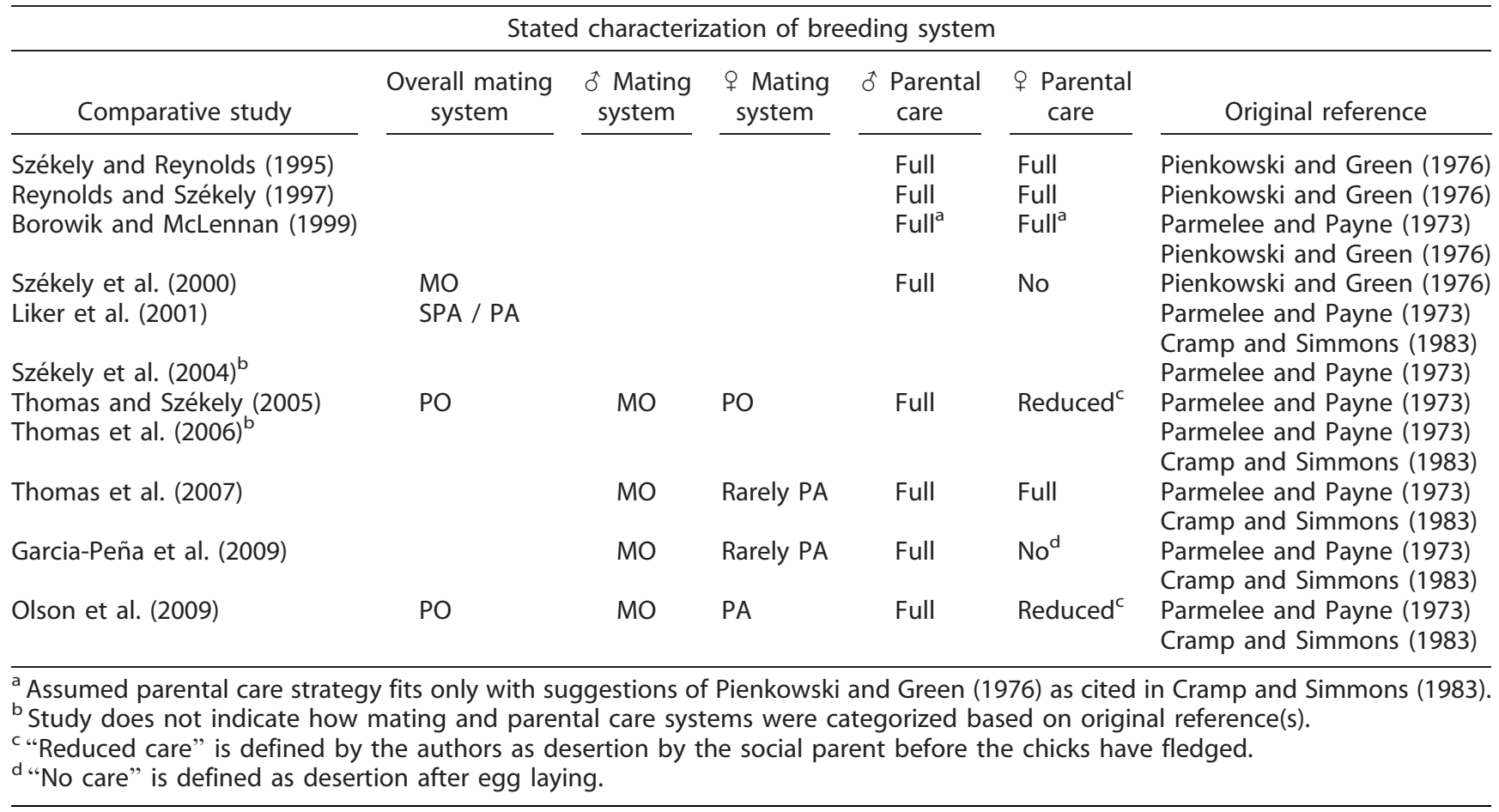

contact calls (Parmelee 1970, J. Reneerkens personal observation). Like almost all sandpipers, they typically lay clutches of 4 eggs, but occasionally smaller clutch sizes occur (Piersma et al. 1996). Clutches are laid in a small scrape on the tundra and are lined with leaves, in Greenland typically of Salix arctica or Dryas integrifolia/ octopetala. Irregular incubation starts when the third egg is laid, and the clutch is intermittently incubated after completion (J. Reneerkens personal observation). According to our own personal observations, egg laying takes 4 days $\left(1\right.$ egg day $\left.^{-1}\right)$. Incubation is assumed to take an additional 22 days as with most other sandpipers (Piersma et al. 1996), but we have not yet been able to verify this for our study population of Sanderlings (Reneerkens et al. 2011). When a clutch is depredated, females may lay a replacement clutch until approximately July 1 (Meltofte et al. 2007) with either the same or a new partner in a nearby territory (J. Reneerkens personal observation). Breeding densities of $0.26-2.9$ pairs, nests, and/or broods $\mathrm{km}^{-2}$ have been reported elsewhere but are higher in Zackenberg (average $=3.7$, range: $3.4-3.9 \mathrm{~km}^{-2}$; Reneerkens et al. 2009). Distances between nests vary considerably, depending on appropriate habitat and snow cover, but occasionally nests are only $50 \mathrm{~m}$ apart (Reneerkens and Grond 2009, J. Reneerkens personal observation). Males show interannual fidelity to their territories, but females usually change territories (Tomkovich and Soloviev 1994), which, on average, are found 1,200 $\mathrm{m}$ away from the location the year before (Reneerkens and Grond 2009, J. Reneerkens personal observation). If a female returns to the area where she incubated in a previous year, she often re-pairs with her previous male (Reneerkens and Grond 2009). Observations of color-ringed individuals suggest that most foraging occurs within $1 \mathrm{~km}$ of the nest (Reneerkens and Grond 2009, J. Reneerkens personal observation).

\section{Fieldwork}

During 6 breeding seasons, in June and July 2003 and 2007-2011, we studied Sanderlings at Zackenberg in northeast Greenland (centered at $74^{\circ} 30^{\prime} \mathrm{N}, 21^{\circ} 00^{\prime} \mathrm{W}$ ). The local breeding population counts are 100-150 breeding pairs (assessment by J. Reneerkens, based on Hansen et al. 2012). Precocial young leave the nest soon after hatching and are often guided by a single parent, and sometimes by both parents. Because of a collapse of the Collared Lemming (Dicrostonyx groenlandicus) population in northeast Greenland and the shift in prey choice by generalist predators such as Arctic foxes (Vulpes lagopus; Schmidt et al. 2012), nest and brood predation at Zackenberg was relatively high $(62 \%$ of nests found in various stages of incubation), which restricted the sampling of nests and broods and repeated observations.

The unit of assessment was a "family," defined as a parental care unit that is either a clutch of eggs or a brood 
TABLE 2. Number of uniparental (Uni) or biparental (Bi) Sanderling clutches found in each year of study. The number of uniparental clutches incubated by either males or females is indicated between brackets. The number of sampled social parents per category is indicated. If 2 parents were sampled from uniparental clutches, 1 adult was genetically assigned as the biological parent. The last column indicates the number of families from which we obtained blood samples from chicks. Because of depredation of clutches, not all chicks or adults could be sampled. Adults found attending clutches in multiple years $(n=18)$ appear in the table more than once.

\begin{tabular}{|c|c|c|c|c|c|}
\hline \multirow[b]{2}{*}{ Year } & \multirow[b]{2}{*}{ Parental care } & \multirow[b]{2}{*}{ Number of clutches found } & \multicolumn{2}{|c|}{ Adults sampled } & \multirow[b]{2}{*}{ Number of families } \\
\hline & & & 1 & 2 & \\
\hline \multirow[t]{4}{*}{2003} & Uni & 0 & 0 & 0 & 0 \\
\hline & $\mathrm{Bi}$ & 9 & 0 & 4 & 3 \\
\hline & Unknown & 8 & 4 & 0 & 3 \\
\hline & Total & 17 & 4 & 4 & 6 \\
\hline \multirow[t]{4}{*}{2007} & Uni & $8(50,3$ ㅇ $)$ & 8 & 0 & 0 \\
\hline & $\mathrm{Bi}$ & 22 & 5 & 17 & 5 \\
\hline & Unknown & 7 & 4 & 0 & 2 \\
\hline & Total & 37 & 17 & 17 & 7 \\
\hline \multirow[t]{4}{*}{2008} & Uni & $12(6 \delta, 6$ \%) & 10 & 1 & 3 \\
\hline & $\mathrm{Bi}$ & 16 & 4 & 11 & 4 \\
\hline & Unknown & 4 & 2 & 1 & 0 \\
\hline & Total & 32 & 16 & 13 & 7 \\
\hline \multirow[t]{4}{*}{2009} & Uni & $13(8$ ठิ, 5 q $)$ & 7 & 5 & 4 \\
\hline & $\mathrm{Bi}$ & 24 & 9 & 15 & 5 \\
\hline & Unknown & 9 & 8 & 0 & 1 \\
\hline & Total & 46 & 24 & 20 & 10 \\
\hline \multirow[t]{4}{*}{2010} & Uni & $7(6 \hat{0}, 1$ o $)$ & 5 & 2 & 1 \\
\hline & $\mathrm{Bi}$ & 6 & 2 & 4 & 4 \\
\hline & Unknown & 13 & 8 & 1 & 2 \\
\hline & Total & 26 & 15 & 7 & 7 \\
\hline \multirow[t]{4}{*}{2011} & Uni & $5(20,3$ o $)$ & 4 & 1 & 4 \\
\hline & $\mathrm{Bi}$ & 13 & 0 & 12 & 7 \\
\hline & Unknown & 12 & 9 & 3 & 2 \\
\hline & Total & 30 & 13 & 16 & 13 \\
\hline \multirow[t]{4}{*}{ Overall } & Uni & $45(27$ ఠิ, 18 ㅇ $)$ & 34 & 9 & 12 \\
\hline & $\mathrm{Bi}$ & 90 & 20 & 63 & 28 \\
\hline & Unknown & 53 & 35 & 5 & 10 \\
\hline & Total & 188 & 89 & 77 & 50 \\
\hline
\end{tabular}

of offspring with 1 or 2 social parents. We found a total of 188 nests (Table 2), and we used a small clap net to capture a total of 268 adult Sanderlings, which we blood sampled (for 125 of these adults, we also sampled their socially associated chicks). We extracted DNA from 178 chicks from 50 nests (Table 2). These numbers comprise individuals captured in all years but exclude subsequent recaptures. Additionally, we found 64 families posthatching, of which we sampled 151 chicks in total (Table 3). These chicks were captured by hand. Individual birds were given unique combinations of color rings and a metal ring. Individual color ringing for identification of each bird, in addition to the temperature profiles in the nests (see below), allowed us to assess the number of adults that incubated a clutch. Also, we were able to recognize the (social) parents in broods away from the nest location. Biometric measures were taken for all individuals, and chick age was estimated from a body-mass-based growth curve (J. Reneerkens personal observation). Small volumes of blood samples $(\sim 50 \mu \mathrm{L})$ were collected from veins in the leg or wing and were stored in ethanol $(96 \%)$ at $-20^{\circ} \mathrm{C}$.

From each clutch, we floated 2 eggs in water to estimate hatching date (Liebezeit et al. 2007). Egg flotation did not affect the hatchability of the eggs (Hansen et al. 2011). In 2007-2011, we placed small temperature loggers (Tiny Tag, Gemini) in 83 nests to determine whether incubation was uniparental or biparental (Reneerkens et al. 2011). Clutches on which we observed $>1$ incubating individual were always considered biparental, even if no thermologgers were used in those nests. Clutches that were left unattended by the incubating bird(s) more than 30 times day $^{-1}$ for $\geq 6$ min were considered uniparental (cf. Reneerkens et al. 2011). In 2007, we confirmed uniparental or biparental incubation on clutches using passive integrated transponders (Reneerkens et al. 2011). Recess frequency depended on the ambient temperature, and, consequently, fewer recesses occurred at night (Reneerkens et al. 2011). Recess frequency better predicted whether 
TABLE 3. Sanderling family-size frequencies found posthatch, according to year and sex of the guarding adult. Blood samples from both chicks and the guiding parent were obtained in 44 of 64 families. In all 3 families that were guided by 2 adults, 1 of them was not the biological parent of any of the chicks; here, they are classified under the sex of the biological parent.

\begin{tabular}{|c|c|c|c|c|c|c|}
\hline \multirow[b]{2}{*}{ Year } & \multirow[b]{2}{*}{$\begin{array}{c}\text { Sex of the } \\
\text { guarding adult }\end{array}$} & \multicolumn{4}{|c|}{ Family size } & \multirow[b]{2}{*}{ Tota } \\
\hline & & $\begin{array}{c}1 \\
\text { chick }\end{array}$ & $\begin{array}{c}2 \\
\text { chicks }\end{array}$ & $\begin{array}{c}3 \\
\text { chicks }\end{array}$ & $\begin{array}{c}4 \\
\text { chicks }\end{array}$ & \\
\hline \multirow[t]{4}{*}{2003} & Male & 3 & 2 & 1 & 2 & 8 \\
\hline & Female & 2 & 0 & 1 & 4 & 7 \\
\hline & Unknown & 1 & 1 & 0 & 0 & 2 \\
\hline & Total & 6 & 3 & 2 & 6 & 17 \\
\hline \multirow[t]{4}{*}{2007} & Male & 0 & 0 & 3 & 2 & 5 \\
\hline & Female & 0 & 1 & 0 & 1 & 2 \\
\hline & Unknown & 2 & 1 & 0 & 2 & 5 \\
\hline & Total & 2 & 2 & 3 & 5 & 12 \\
\hline \multirow[t]{4}{*}{2008} & Male & 2 & 0 & 0 & 0 & 2 \\
\hline & Female & 1 & 1 & 0 & 1 & 3 \\
\hline & Unknown & 2 & 0 & 0 & 0 & 2 \\
\hline & Total & 5 & 1 & 0 & 1 & 7 \\
\hline \multirow[t]{4}{*}{2009} & Male & 1 & 1 & 2 & 0 & 4 \\
\hline & Female & 0 & 0 & 2 & 1 & 3 \\
\hline & Unknown & 3 & 3 & 2 & 0 & 8 \\
\hline & Total & 4 & 4 & 6 & 1 & 15 \\
\hline \multirow[t]{4}{*}{2010} & Male & 0 & 0 & 1 & 1 & 2 \\
\hline & Female & 0 & 1 & 0 & 1 & 2 \\
\hline & Unknown & 0 & 1 & 1 & 0 & 2 \\
\hline & Total & 0 & 2 & 2 & 2 & 6 \\
\hline \multirow[t]{4}{*}{2011} & Male & 0 & 3 & 0 & 0 & 3 \\
\hline & Female & 2 & 1 & 0 & 0 & 3 \\
\hline & Unknown & 1 & 0 & 0 & 0 & 1 \\
\hline & Total & 3 & 4 & 0 & 0 & 7 \\
\hline \multirow[t]{3}{*}{ Overall } & Male & 6 & 6 & 7 & 5 & 24 \\
\hline & Female & 5 & 4 & 3 & 8 & 20 \\
\hline & Unknown & 9 & 6 & 3 & 2 & 20 \\
\hline \multicolumn{7}{|l|}{ Overall } \\
\hline total & & 20 & 16 & 13 & 15 & 64 \\
\hline
\end{tabular}

clutches were incubated uniparentally or biparentally than recess length (Reneerkens et al. 2011). Overall, the threshold of 30 recesses day ${ }^{-1}$ clearly distinguished uniparental and biparental clutches (Reneerkens et al. 2011). Indeed, we never observed biparental incubation at clutches that were left unattended $>30$ times day ${ }^{-1}$. Four freshly hatched clutches, and 6 clutches expected to hatch within 2 days, were not equipped with data loggers but were visited daily (cf. Tulp and Schekkerman 2006). Clutches were revisited $\leq 8$ times to assess the presence of and capture the second incubating adult. On confirmed biparental clutches, the second partner was usually encountered during the second visit (average $=2.4$; range: 1-4 visits; Reneerkens et al. 2011).

Biparental incubation later became uniparental incubation in 3 cases. This was established on the basis of temperature logger profiles (Reneerkens et al. 2011) and confirmed by repeated visual observations of the same color-ringed bird incubating the clutch after the desertion of one parent. These cases were classified as uniparental. We consider it unlikely that depredation of adults, instead of desertion, occurred. The only avian predator of adult sandpipers in the study area, Gyrfalcon (Falco rusticolus), is a rare visitor and mainly occurs outside the incubation period of Sanderlings (mid-June to the end of July; Hansen et al. 2012). We never found prey remains of adult Sanderlings near a nest typical of predation by mammalian predators, which would, moreover, also have taken the clutch. Also, 1 of the 3 individuals was observed alive after desertion. Early clutch predation and posthatching discovery of families restricted data on incubation patterns. We made notes of the identity of adults guiding hatched chicks. The chicks were always captured and blood sampled, but the attending adult was captured and blood sampled in only 47 of 66 broods (71\%). If chicks hatched from a known clutch, we were often able to assess whether 1 or 2 adults incubated the clutch; but for families found, posthatch, away from the nest (a "brood"), no information on incubation behavior was available.

\section{Molecular Methods and Assignments}

Total cellular DNA was extracted from blood following the protocol of Richardson et al. (2001), with some optimization adjustments. For each individual, sex was assayed following Fridolfsson and Ellegren (1999) using calidridadjusted primers 2602F and 2669R (Luttikhuizen et al. 2011, O. Haddrath personal communication). On three occasions ( 2 adults and 1 chick), DNA extracts failed to amplify. Although the sex of the 2 adults could unambiguously be determined on the basis of sex-specific size and plumage characteristics (J. Reneerkens personal observation), the chick remained unsexed.

For parentage analysis (i.e. assessing biological maternity and paternity), we used 7 microsatellite markers selected for high polymorphism and nonoverlapping allele size ranges of the loci (an3, gt22b, gt24b, Cme 1, 3, 6, and 9; described by Carter and Kempenaers 2007, Luttikhuizen et al. 2011; Table 4). Polymerase chain reactions (PCR) were carried out in $10 \mu \mathrm{L}$ volume containing $1 \times$ PCR Buffer $(10$ $\mathrm{mM}$ Tris- $\mathrm{HCl}, \mathrm{pH}$ 8.3, $50 \mathrm{mM} \mathrm{KCl}, 2.5 \mathrm{mM} \mathrm{MgCl}, 0.01 \%$ gelatin), $200 \mu \mathrm{M}$ dNTP, $0.2 \mu \mathrm{M}$ F primer, $0.2 \mu \mathrm{M}$ R primer, $0.2 \mu \mathrm{M}$ universal 6-FAM, HEX or NED fluorescent dyelabeled M13 (5'-TGTAAAACGACGGCCAGT-3') tail, 0.25 units Taq polymerase (Roche, Penzberg, Germany), and 50 ng DNA template. The PCR reactions were run on a Thermal Cycler (Applied Biosystems, Foster City, California, USA) or a Mastercycler (Eppendorf, Hamburg, Germany). The PCR profile for an $3: 2$ min $94^{\circ} \mathrm{C}, 36$ cycles of $94^{\circ} \mathrm{C}$ for $30 \mathrm{~s}, 55^{\circ} \mathrm{C}$ for $60 \mathrm{~s}$, and $72^{\circ} \mathrm{C}$ for $90 \mathrm{~s}$, followed by $72^{\circ} \mathrm{C}$ for $7 \mathrm{~min}$. The PCR profile for the other 6 loci was $2 \mathrm{~min}$ at $94^{\circ} \mathrm{C}, 15$ cycles of $94^{\circ} \mathrm{C}$ for $30 \mathrm{~s}, 56^{\circ} \mathrm{C}$ for $90 \mathrm{~s}$ and $72^{\circ} \mathrm{C}$ for $60 \mathrm{~s}, 20$ cycles of $94^{\circ} \mathrm{C}$ for $30 \mathrm{~s}, 60^{\circ} \mathrm{C}$ for $90 \mathrm{~s}$, and $72^{\circ} \mathrm{C}$ for $60 \mathrm{~s}$, followed by $60^{\circ} \mathrm{C}$ for $30 \mathrm{~min}$ and cool-down 
TABLE 4. Characteristics of microsatellite markers for genetic parentage analysis in adult Sanderlings $\left(N_{\mathrm{A}}=\right.$ number of alleles, $N_{\mathrm{T}}=$ number of individuals genotyped, $H_{\mathrm{O}}=$ observed heterozygosity, $H_{\mathrm{E}}=$ expected heterozygosity, Freq $\mathrm{NULL}_{\mathrm{L}}=$ estimated null allele frequency, Sig = significance, and $P_{\mathrm{ID}}=$ probability of identity). Marker an3 is included. After exclusion of an3, no markers deviated significantly from Hardy-Weinberg equilibrium (HWE).

\begin{tabular}{lccccrrr}
\hline Locus & $N_{\mathrm{A}}$ & $N_{\mathrm{T}}$ & $H_{\mathrm{O}}$ & $H_{\mathrm{E}}$ & Freq & SULL & $P_{\mathrm{ID}}$ \\
\hline an3 $^{\mathrm{a}}$ & 20 & 259 & 0.737 & 0.886 & 0.0906 & 0.0000 & $2.33 \times 10^{-2}$ \\
gt22b $_{\text {gt24b }}$ & 11 & 255 & 0.686 & 0.718 & 0.0249 & 0.3284 & $1.22 \times 10^{-1}$ \\
Cme1 & 16 & 266 & 0.767 & 0.776 & 0.0065 & 0.6440 & $7.89 \times 10^{-2}$ \\
Cme3 $^{\mathrm{a}}$ & 16 & 265 & 0.845 & 0.877 & 0.0193 & 0.2904 & $2.70 \times 10^{-2}$ \\
Cme6 $_{\text {Cme9 }}^{17}$ & 16 & 253 & 0.806 & 0.897 & 0.0542 & 0.0005 & $1.95 \times 10^{-2}$ \\
Overall & 10 & 267 & 0.828 & 0.805 & -0.0167 & 0.0731 & $5.91 \times 10^{-2}$ \\
\hline
\end{tabular}

${ }^{a}$ Significant deviations from HWE (Bonferroni corrected) if estimated null allele frequency is $>0.05$.

to $8^{\circ} \mathrm{C}$. Fluorescently labeled PCR products were analyzed on a 3730 DNA Analyzer (Applied Biosystems), and allele sizes were scored using GeneMapper version 4.0 (Applied Biosystems).

Of 407 sampled individuals, 91\% were genotyped in all 7 loci, $8.1 \%$ at 6 loci, $0.7 \%$ at 5 loci, and $0.2 \%$ at 4 loci only. All microsatellite markers were highly polymorphic (Table 4). Evidence for null alleles at microsatellite loci and the presence of identical genotypes in the population were examined using the allele frequency analysis and identity analysis functions in CERVUS version 3.0, respectively. Within 2 loci, significant estimates of homozygote excess were found and the associated estimates of null allele frequencies were substantial $(9.1 \%$ and $5.4 \%$ in an 3 and Cme3, respectively; Table 4). However, in our dataset, direct comparison of these alleles between social parent and their associated offspring showed lower actual null allele frequencies (4.9\% of all chicks in an 3 and $0.9 \%$ in Cme3). To maintain a high resolution for our paternity analysis, and especially because of the low null allele frequency in the data, we did not exclude Cme3.

Allele frequency analysis showed that the probability of two random individuals having the same genotype was 1.2 $\times 10^{-9}$, and our data contained no identical genotypes. Tests for linkage disequilibrium were carried out using GENEPOP version 4.0 (Rousset 2008), but the test results did not yield statistical significance after Bonferroni correction for multiple comparisons (21 tests; critical $P$ value $=0.00238$, lowest observed $P$ value $=0.00385)$. Tests for deviations from Hardy-Weinberg equilibrium (HWE) revealed a global departure from HWE with an3 included in the test $(P<0.001)$, but after exclusion of an3, no departure from HWE was found among the remaining 6 loci $(P>0.05)$.

Comparisons of microsatellite genotypes of offspring and social parents were used to assess genetic parentage. First, we checked whether the observed social parent(s) were indeed the genetic parent(s). We used a set of strict rules to genetically confirm social parents and to assign unknown genetic parents. (1) Only parent-offspring pairs for which $\geq 5$ loci could be compared were taken into account; on this basis, 1 family was excluded from all analyses. (2) Genetic maternity or paternity of social parents was confirmed when at least all but 1 of the measured loci matched between parent and young. Genetic parentage was thus rejected at $\geq 2$ mismatches, and chicks were then considered extrapair young (EPY) (cf. Griffith et al. 1999, Otter et al. 2001). (3) Alleged null alleles at locus an3 and Cme3 were not regarded as mismatches.

We attempted to assign (unknown) genetic parents if one of the social parents was unknown or for EPY for which 1 of the known social parents could be excluded. Paternity or maternity was assigned to candidate parents conservatively: only if genotypes of parent and offspring matched for all loci (minimum 5). When we failed to assign parentage to an adult that was sampled in the same field season as the offspring in question, we looked for candidates among all sampled birds during the entire study period (134 males and 134 females), following the same protocol. We found 4 additional mothers and 3 additional fathers among this sample of all possible candidates.

We used CERVUS to search for putative genetic parents on the basis of 6 microsatellite markers (Marshall et al. 1998, Kalinowski et al. 2007). Only adults with no mismatches were selected. Subsequently, for additional confirmation, matching of microsatellite genotypes of the candidate parent with the presumed offspring were examined by eye once again, with the highly polymorphic marker an3 also taken into account when both adults were heterozygous for this locus; thus, we could confirm the absence of null alleles. Using CERVUS, the probability of exclusion for the 6 loci (an3 excluded) used to allocate (unknown) parents was $P=0.9999$ if both parents were known, and $P=0.9994$ with 1 known parent. In case of 


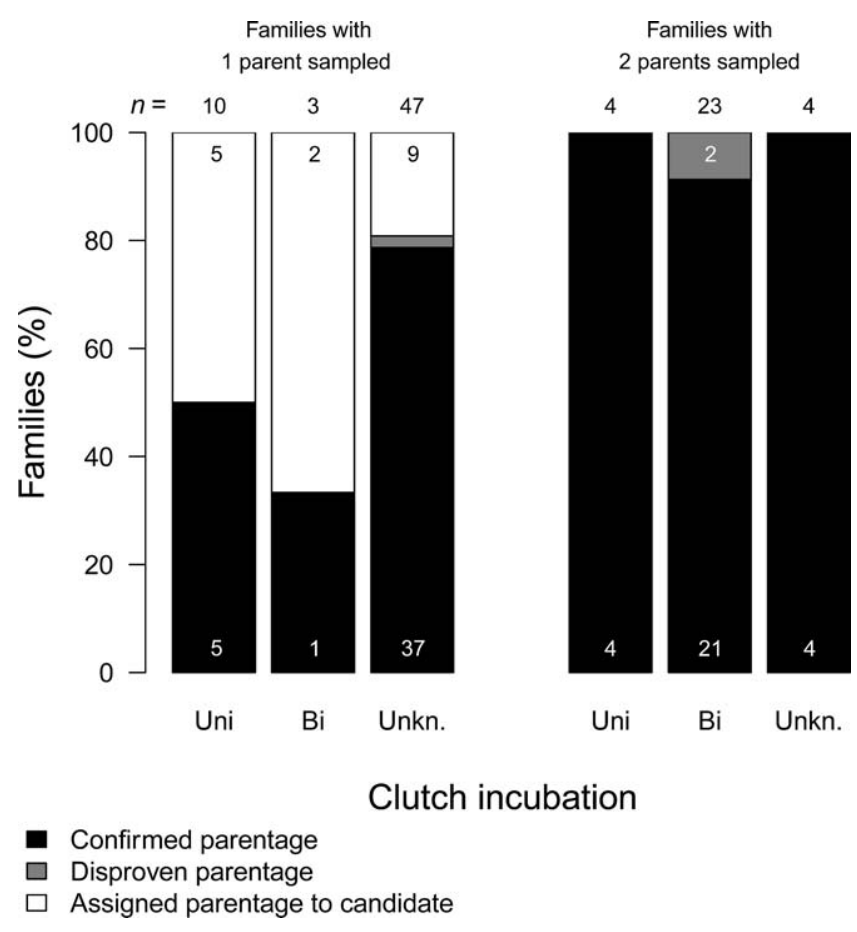

FIGURE 1. Number of Sanderling families ( $n$ denoted in bars) for which parentage was confirmed or rejected for social parents or assigned to a candidate parent, in relation to the total number of families (total $n$ denoted above bars). Two groups of families are examined: families with chicks and only 1 parent sampled, and families with chicks and 2 parents sampled. Families are sorted by the number of incubating parents (Uni = uniparental; $\mathrm{Bi}=$ biparental; Unkn. = unknown number of incubating parents).

equal likelihood of genetic paternity of 2 candidates, we assumed that the social parent was also the genetic parent.

\section{Definitions of Mating Systems}

We distinguished three genetic mating systems: (1) genetic monogamy, (2) genetic polyandry, and (3) genetic polygyny. We considered a pair socially monogamous when it shared incubation of a clutch (biparental incubation). If both were biological parents, without evidence that any of them sired offspring with another adult, we considered them also genetically monogamous. We note that genetic monogamy is difficult to prove without a complete sampling of a population's offspring. Among the polygamous breeding styles, we differentiated genetic polyandry as when a female produced multiple clutches with different biological fathers. The mating system was considered genetic polygyny when a male fertilized complete clutches of multiple females. We stress that, although these definitions are exclusive and clearcut at the genetic level, they are not so at the level of the social mating system. The field situation did not allow obtaining sufficiently detailed social data to make inferences of social pair bonds, but following previous studies of social mating systems in shorebirds (e.g., Wallander et al. 2001), we considered a pair socially monogamous if the participating male and female shared incubation. Furthermore, because parentage must be proven in $>1$ clutch in cases of genetic polygamy (i.e. polyandry and polygyny), polygamy will be considerably more difficult to pin down than genetic monogamy, particularly in the High Arctic, where high rates of clutch predation (McKinnon et al. 2010) limit the proportion of offspring that can be sampled for DNA. Extrapair paternity (i.e. when other males in addition to the social male contributed to the genetic composition of a clutch) is not considered a distinct genetic mating strategy, but it can occur in either previously described genetic mating system. Extrapair young in a genetically monogamous family can be distinguished from genetic polygyny only if the biological father of the extrapair young was known to also be the biological parent of chicks in another family.

\section{RESULTS}

\section{Parental Care}

Examination of incubation patterns of 188 clutches revealed that 45 clutches received uniparental incubation ( 27 by males and 18 by females) and 90 clutches biparental incubation. For the remaining 53 families, no incubation assessment could be carried out (Table 2). In 3 cases, temperature profiles indicated biparental incubation, but a second parent could not be captured. In 4 cases, we found uniparental incubation in families of which 2 social adults were sampled (Figure 1). In such cases, 1 parent may have deserted the clutch. At least 5 birds (4 males, 1 female) adopted different patterns of care (uniparental or biparental incubation) in different years.

We also found evidence for brood division (in which parents observed to share incubation duties on a single clutch independently guided part of their brood). One particular case of brood division was revealed by the genetic data rather than behavioral data, because the genetic parents were independently guiding different broods. Encountered 3 days apart, the father guided 1 young and the mother 2 others, but genetic data showed joint genetic parentage for the 3 chicks.

We found no evidence of conspecific brood parasitism. However, among families that were encountered posthatch, genetic parentage by one or both social parents was rejected for 9 young from 4 families. These young could have resulted from extrapair paternity or from adoption. Two uniparental fathers guided chicks that were not their own. These could be cases of extrapair paternity but might also represent brood mixing or adoption. In one case, we confirmed brood mixing, or adoption, in a family consisting of 5 young guided by 2 adults. Observing 5 
TABLE 5. Numbers of Sanderling families of different genetic mating systems in different years. The number of families with extrapair paternity (EPP) is indicated. The number of extrapair young is indicated in parentheses if they occurred. The clutch size was 4 in all cases of EPP.

\begin{tabular}{|c|c|c|c|c|c|c|}
\hline \multirow[b]{2}{*}{ Year } & \multicolumn{2}{|c|}{ Monogamy } & \multicolumn{2}{|c|}{ Polyandry } & \multicolumn{2}{|c|}{ Polygyny } \\
\hline & Families & $\begin{array}{l}\text { Families } \\
\text { with EPP }\end{array}$ & Families & $\begin{array}{l}\text { Families } \\
\text { with EPP }\end{array}$ & Families & $\begin{array}{l}\text { Families } \\
\text { with EPP }\end{array}$ \\
\hline 2003 & 4 & $1(4)^{a}$ & & & & \\
\hline 2007 & 4 & 0 & & & & \\
\hline 2008 & 4 & 0 & 2 & $0(1)^{\mathrm{b}}$ & & \\
\hline 2009 & 8 & 0 & 1 & 0 & 1 & 0 \\
\hline 2010 & 4 & 0 & 1 & 0 & & \\
\hline 2011 & 9 & $1(1)$ & & & 1 & 0 \\
\hline Total & 33 & 2 & 4 & 0 & 2 & 0 \\
\hline
\end{tabular}

${ }^{a}$ This was a biparental, socially monogamous pair, but it was not genetically monogamous. The male incubated a full clutch of unrelated offspring, and the biological father could not be assigned.

${ }^{b}$ DNA was extracted from 3 offspring only. The clutch with EPY was uniparentally incubated by the female, and no social male was observed.

chicks in one brood, which is unusual in Sanderlings, already suggests brood mixing in the field. One young appeared to be incompatible with the genotypes of both social parents and was $\sim 8$ days older than all other chicks. The striking genotypic difference implies that this unrelated young most likely originated from a different family. One of the 4 other chicks was an EPY; it only matched the genotype of the social mother.

Chicks were generally guided by 1 adult ( 24 families by a male, 20 by a female, and 20 by an adult of unknown sex; Table 3). In 2 exceptional cases in which a brood was guided by both a male and a female, 1 of the parents that showed care (alarming, chasing away Long-tailed Jaegers [Stercorarius longicaudus], and/or brooding the chicks) was not a biological parent of the chicks.

\section{Paternity Analysis}

Of all 188 families encountered during the incubation period, we obtained a DNA sample from 2 social parents in 77 families (Table 2). We obtained samples from both social parents and at least 1 chick in 31 families (Figure 1). Obviously, only 1 social parent could be sampled for uniparental clutches. In 20 biparental clutches, we sampled DNA of only 1 adult because clutch predation took place before capture of the second adult (Table 2). Parents genetically matched all of their social offspring in 29 of 31 cases for which we managed to sample both social parents' DNA. In the remaining 2 families, 6 of 8 chicks failed to match their social parents.

Overall, in 48 Sanderling families, both social parents (based on observations) could be confirmed through parentage analysis or candidate parents were assigned to some or all young. Only 3 families (6.3\%) contained EPY (Table 5). On average, $2.0 \%$ of all offspring were EPY (i.e. 7 EPY out of 342 young sampled with attending parent(s); 0$6.5 \%$ between years). EPY showed two $(n=2)$, three $(n=4)$, or four $(n=1)$ mismatching loci with the social father. When families were sampled after hatch (i.e. when they have moved away from the nest cup), EPY and adoption cases could not be distinguished. We found missing parents in $26.7 \%$ ( $n=16$ of 60$)$ of the families that were encountered posthatch and of which we sampled 1 parent. The assigned putative parents matched for 34 of 50 young in these 16 families. We note that most nonmatching chicks were likely to be genetic offspring as well, but parents could not be assigned because of our conservative assignment approach, which did not allow any mismatches. Twenty-seven young showed 1 mismatch with a social parent, but these were scored as within-pair offspring (see Methods).

Our data corroborate the notion that in many families for which biparental care was demonstrated, the 2 social parents were indeed related to their chicks $(68.8 \%, n=33$ of 48 families). Such cases were classified as socially and genetically monogamous (Table 5). For 2 pairs performing biparental clutch incubation in which only 1 of the parents could be assayed for parentage, there was no further evidence for genetic polygamy. In 2 other cases, we confirmed that replacement clutches contained offspring of both social partners, and both were incubated by uniparental males.

\section{Genetic Mating Systems}

Our genetic data further demonstrate that polygamy occurred only in uniparentally incubated clutches. Specifically, polygamy occurred in $42.9 \%(n=6$ of 14) of uniparentally incubated clutches for which we found the second biological parent, but not in completely sampled biparental families $(n=26)$; this difference in relative frequency of polygamy was significant (Fisher's exact test, $P<0.001$ ). We found 6 cases of polygamy: 4 cases of polyandry and 2 cases of polygyny (see Table 6). This means that polygamy occurred in $12.5 \%(n=6$ of 48$)$ of the completely assayed families.

The genetic evidence of polygamy with a diversity of mating systems (Table 5) is supported by observations of breeding behavior. A convincing case of polyandry was a female who was assigned maternity to 2 clutches with 3 fathers. The first-laid clutch hatched on July 14, 2008, after uniparental incubation by the biological father of all 4 young. The female provided uniparental care on her second clutch of 4 eggs. The 3 chicks from which we were able to extract DNA had 2 other biological fathers and hatched on July 18, 2008. Hatch dates between the clutches differed by precisely 4 days, implying that this female laid 2 


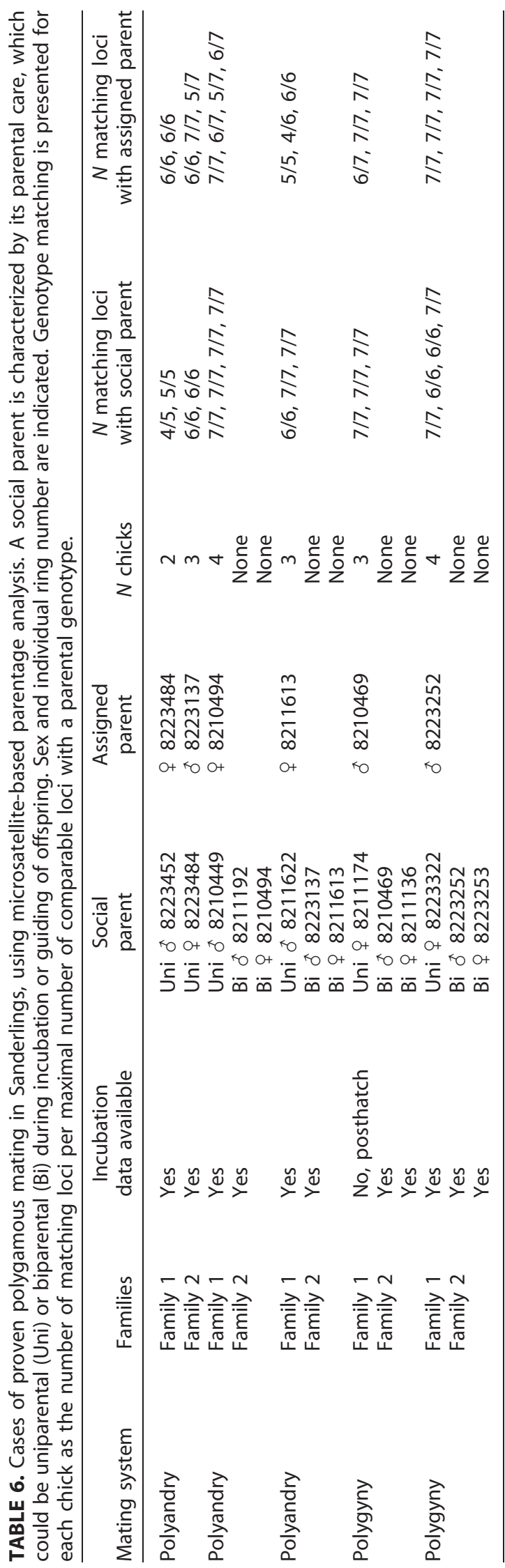

clutches without pausing. The father of 2 of the chicks arrived late in the breeding area. Despite our 5 visits to his territory and surroundings between June 1 and 9 , he was only observed that year on June 11, engaged in a prolonged display flight. He remained unpaired for 2 wk at the territory he held for several years and was not observed in 2008 after June 25. Eventually, he sired 2 EPY, 7 km north of his territory. Comparing the expected incubation period of 22 days with these hatch dates and the male's departure date from his territory, fertilization should have been achieved on June 26, 1 day after the departure from his territory.

Two cases of polygyny were revealed (Table 5). One case concerned a pair maintaining a pair bond throughout three consecutive breeding seasons and providing biparental incubation at their clutches. In 2011, their clutch and a subsequent replacement clutch were depredated. Additionally, this male sired all offspring at a third clutch, for which a single female provided uniparental care. The uniparental clutch hatched only 5 days later than the predicted hatch day of the male's first biparental clutch, and the distance between the two nests was only a few hundred meters. The male was seen foraging near the nest of the uniparental female, though he chased her away when she approached his first nest. Taken together, these findings show that this male engaged in polygynous mating. Details of the other case of polygyny and of two other polyandry cases can be found in Table 6 .

\section{DISCUSSION}

Characterizing the mating system of Sanderlings as "socially monogamous" (Székely et al. 2000) does not accurately represent the diversity in breeding strategies we describe here. We show the persistent within-season pair bonds and shared parental duties that characterize social monogamy, and the low frequency of extrapair fertilizations (2.0\% of all 342 young, $6.3 \%$ of 48 families for which both putative parents were sampled) lies within the range of other shorebird species classified as socially and genetically monogamous (e.g., Blomqvist et al. 2002a). However, the large proportion of uniparental incubation is atypical for a socially monogamous shorebird species (e.g., Wallander et al. 2001). We also detected 6 cases of genetic polygamy. Nevertheless, classifying Sanderlings as genetically polyandrous or polygynous would also be inappropriate, given that neither of these systems predominated.

We suggest that the actual frequency of polygamous mating might be considerably higher than presented here. Uniparental incubation is often the result of a partner deserting a clutch (J. Reneerkens personal observation), which would enable individuals to search for extra mating opportunities. Indeed, 6 of 16 families (37.5\%) with 
assigned second parents actually engaged in polygamy. The frequent occurrence of uniparental clutches in Sanderlings might, thus, further indicate that polygamy is more common than we were able to demonstrate genetically. Despite our thorough sampling efforts, information on parentage of 43 families for which only 1 parent was sampled remained incomplete. Of the 135 clutches for which we could assess incubation patterns, 45 (33\%) were uniparental (Table 2), and one classification (uniparental or biparental incubation) for the species is thus inadequate.

Annual variation in predator abundance could promote within-population variation in parental care systems of the Sanderling. Incubation by uniparental Sanderlings is much more frequently interrupted by foraging trips off the nest, compared with shared incubation (Reneerkens et al. 2011). High levels of movement near the nest might increase the chances that nests are detected by predators (Ghalambor and Martin 2002, Smith et al. 2010). It has been shown experimentally that passerines can adjust their incubation behavior in response to the presence or absence of predators (Fontaine and Martin 2006). Variation in clutch survival among Arctic shorebird species has been related to whether species show uniparental or biparental incubation (Smith and Wilson 2010) and is correlated with the total time spent off the nest (Smith et al. 2010).

Clearly, both male and female Sanderlings make variable mating and parental care decisions, and both sexes likely responded to their social and environmental conditions, the nature of which we have to examine next. For some clutches, parental care switched from biparental to uniparental incubation upon clutch desertion. This would have created mating opportunities for the deserting partner, as well as associated incubation costs for the deserted partner (Reneerkens et al. 2011). Furthermore, we show the occasional occurrence of brood division and brood amalgamation ("adoption"; see Lanctot et al. 1995) among socially and genetically monogamous pairs.

Behavioral ecologists have long recognized that simple categorizations of mating systems and parental care are inadequate and do not capture underlying complexity (e.g., Davies 1991). Shuster and Wade (2003) discussed a comprehensive theoretical classification scheme for mating systems using spatiotemporal distributions of female availability, but they acknowledged that the necessary quantitative estimates are unknown for most species. Given the large intrapopulation variation in breeding decisions of the Sanderling and other shorebird species (e.g., Székely et al. 2007), the standard approach of phylogenetic comparative studies of breeding systems (i.e. the assignment to categories at the species level; Thomas and Székely 2005, Olson et al. 2009) may not be applicable and warrants reconsideration. Special care is also necessary because the majority of descriptions of breeding systems of shorebird species used in the phylogenetic comparative studies were based on interpretations of observed behavior, without genetic support (e.g., MacLean 1969, Nettleship 1973, Gratto-Trevor 1991; but see, e.g., Wallander et al. 2001, Blomqvist et al. 2002b). Although the breeding biology of some shorebirds has certainly been comprehensively studied, for example, in the Kentish Plover (Charadrius alexandrinus; Küpper et al. 2004), Red-necked Phalarope (Phalaropus lobatus; Schamel et al. 2004), and Northern Lapwing (Vanellus vanellus; Grønstøl et al. 2006), more data are needed on genetic mating systems and intraspecific variation in breeding decisions in most shorebirds (Székely et al. 2007).

Despite various published phylogenetic comparative analyses of numerous taxa that necessarily classified complex behavior at the species level (e.g., Olson et al. 2008, Tökölyi and Barta 2011, Lapiedra et al. 2013), we are not aware of studies addressing the consequences of inadequate classification in this approach. We argue that phylogenetic comparative analyses of shorebird mating strategies would result in more reliable conclusions if they allowed for variation within species and populations. This would better enable us to appreciate the importance of ecological opportunity in shaping the intriguing variation in shorebird breeding systems seen today. For example, Hasselquist and Sherman (2001) compared phylogenetic contrasts and, also, species-level data of temperate-zone passerine bird species based on either a dichotomous (monogamous or polygynous) or a continuous (proportion of males with $>1$ social mate) characterization of extrapair fertilizations based on molecular parentage analyses. We propose that we need such continuous characterizations to adequately analyze shorebird mating strategies.

Furthermore, we also require reliable input. Even if shorebird populations are studied in extensive detail, social and genetic monogamy will remain easier to detect than polygamy. We thus plead for caution in the application and interpretation of phylogenetic comparative analyses of shorebird mating systems. Earlier conclusions from the standard comparative analyses (summary in Table 1) need reexamination and may not hold up. In view of the probably common variability within species, methods of comparison may well need elaboration too.

\section{ACKNOWLEDGMENTS}

We thank the Zackenberg Logistical team at the Department of Bioscience-Roskilde, Aarhus University, for providing logistics at the research station at Zackenberg, northeast Greenland. This work was supported by an International Polar Year grant to T.P. and J.R. J.R also received an INTERACT 
grant for Transnational Access from the European Community's Seventh Framework Programme under grant agreement no. 262693. K. Dijksterhuis, S. van den Eertwegh, P. de Goeij, K. Grond, G. T. Hallgrimsson, J. Hansen, L. Hofstee, J. Hooijmeijer, J. Jukema, J. van der Kamp, L. Kooistra, J. de Raad, H. Schekkerman, K. de Rijk, I. Tulp, and T. Voets provided invaluable assistance in the field, and S. van den Eertwegh also in the laboratory. We thank A. Bol, J. van Bleijswijk, and $\mathrm{H}$. Witte for their support with the early molecular work. Comments by J. Conklin, B. Kempenaers, Y. Verkuil, anonymous reviewers, and editors improved the manuscript.

\section{LITERATURE CITED}

Bennett, P. M., and I. P. F. Owens (2002). Evolutionary Ecology of Birds: Life Histories, Mating Systems and Extinction. Oxford University Press, Oxford, UK.

Blomqvist, D., M. Andersson, C. Küpper, I. C. Cuthill, J. Kis, R. B. Lanctot, B. K. Sandercock, T. Székely, J. Wallander, and B. Kempenaers (2002a). Genetic similarity between mates and extra-pair parentage in three species of shorebirds. Nature 419:613-615.

Blomqvist, D., B. Kempenaers, R. B. Lanctot, and B. K. Sandercock (2002b). Genetic parentage and mate guarding in the Arcticbreeding Western Sandpiper. The Auk 119:228-233.

Borowik, O. A., and D. A. McLennan (1999). Phylogenetic patterns of parental care in calidridine sandpipers. The Auk 116:1107-1117.

Carter, K. L., and B. Kempenaers (2007). Eleven polymorphic microsatellite markers for paternity analysis in the Pectoral Sandpiper, Calidris melanotos. Molecular Ecology Notes 7: 658-660.

Cramp, S., and K. E. L. Simmons (Editors) (1983). The Birds of the Western Palearctic, vol. III. Oxford University Press, Oxford, UK.

Dale, J., R. Montgomerie, D. Michaud, and P. T. Boag (1999). Frequency and timing of extrapair fertilisation in the polyandrous Red Phalarope (Phalaropus fulicarius). Behavioral Ecology and Sociobiology 46:50-56.

Davies, N. B. (1991). Mating systems. In Behavioural Ecology: An Evolutionary Approach, 3rd ed. (J. R. Krebs and N. B. Davies, Editors). Blackwell Scientific, Oxford, UK. pp. 263-294.

Emlen, S. T., and L. W. Oring (1977). Ecology, sexual selection, and evolution of mating systems. Science 197:215-223.

Figuerola, J. (1999). A comparative study on the evolution of reversed size dimorphism in monogamous waders. Biological Journal of the Linnean Society 67:1-18.

Fontaine, J. J., and T. E. Martin (2006). Parent birds assess nest predation risk and adjust their reproductive strategies. Ecology Letters 9:428-434.

Fridolfsson, A. K., and H. Ellegren (1999). A simple and universal method for molecular sexing of non-ratite birds. Journal of Avian Biology 30:116-121.

Garcia-Peña, G. E., G. H. Thomas, J. D. Reynolds, and T. Székely (2009). Breeding systems, climate, and the evolution of migration in shorebirds. Behavioral Ecology 20:1026-1033.

Ghalambor, C. K., and T. E. Martin (2002). Comparative manipulation of predation risk in incubating birds reveals variability in the plasticity of responses. Behavioral Ecology 13:101-108.

Gratto-Trevor, C. L. (1991). Parental care in Semipalmated Sandpipers Calidris pusilla: Brood desertion by females. Ibis 133:394-399.

Griffith, S. C., I. R. K. Stewart, D. A. Dawson, I. P. F. Owens, and T. Burke (1999). Contrasting levels of extra-pair paternity in mainland and island populations of the House Sparrow (Passer domesticus): Is there an 'island effect'? Biological Journal of the Linnean Society 58:303-316.

Grønstøl, G., D. Blomqvist, and R. H. Wagner (2006). The importance of genetic evidence for identifying intra-specific brood parasitism. Journal of Avian Biology 37:197-199.

Hansen, J., L. H. Hansen, N. M. Schmidt, and J. Reneerkens (2012). Bird monitoring at Zackenberg, northeast Greenland, 2010, with comparison with 1996-2009. Bird Populations 11:42-52.

Hansen, J., N. M. Schmidt, and J. Reneerkens (2011). Egg hatchability in High Arctic breeding wader species Charadriiformes is not affected by determining incubation stage using the egg flotation technique. Bird Study 58:522-525.

Hasselquist, D., and P. W. Sherman (2001). Social mating systems and extrapair fertilizations in passerine birds. Behavioral Ecology 12:457-466.

Kalinowski, S. T., M. L. Taper, and T. C. Marshall (2007). Revising how the computer program CERVUS accommodates genotyping error increases success in paternity assignment. Molecular Ecology 16:1099-1106.

Kosztolányi, A., T. Székely, I. C. Cuthill, K. T. Yilmaz, and S. Berberoğlu (2006). Ecological constraints on breeding system evolution: The influence of habitat on brood desertion in Kentish Plover. Journal of Animal Ecology 75:257-265.

Küpper, C., J. Kis, A. Kosztolanyi, T. Székely, I. C. Cuthill, and D. Blomqvist (2004). Genetic mating system and timing of extrapair fertilizations in the Kentish Plover. Behavioral Ecology and Sociobiology 57:32-39.

Lanctot, R. B., R. E. Gill, Jr., T. L. Tibbitts, and C. M. Handel (1995). Brood amalgamation in the Bristle-thighed Curlew Numenius tahitiensis: Process and function. Ibis 137:559-569.

Lapiedra, O., D. Sol, S. Carranza, and J. M. Beaulieu (2013). Behavioural changes and the adaptive diversification of pigeons and doves. Proceedings of the Royal Society of London, Series B 280:20122893.

Lappo, E., P. Tomkovich, and E. Syroechkovsky (2012). Atlas of breeding waders in the Russian Arctic. Institute of Geology, Russian Academy of Sciences, Moscow, Russia.

Liebezeit, J. R., P. A. Smith, R. B. Lanctot, H. Schekkerman, I. Tulp, S. J. Kendall, D. M. Tracy, R. J. Rodrigues, H. Meltofte, J. A. Robinson, C. Gratto-Trevor, B. J. McCaffery, et al. (2007). Assessing the development of shorebird eggs using the flotation method: Species-specific and generalized regression models. The Condor 109:32-47.

Ligon, J. D. (1999). The Evolution of Avian Breeding Systems. Oxford University Press, Oxford, UK.

Liker, A., J. D. Reynolds, and T. Székely (2001). The evolution of egg size in socially polyandrous shorebirds. Oikos 95:3-14.

Luttikhuizen, P. C., A. Bol, H. Witte, J. van Bleijswijk, O. Haddrath, A. J. Baker, T. Piersma, and J. Reneerkens (2011). Novel and cross-species microsatellite markers for parentage analysis in Sanderling Calidris alba. Journal of Ornithology 152:807-810. 
MacLean, G. L. (1969). A study of seedsnipe in southern South America. Living Bird 8:33-80.

Marshall, T. C., J. Slate, L. E. B. Kruuk, and J. M. Pemberton (1998). Statistical confidence for likelihood-based paternity inference in natural populations. Molecular Ecology 7:639-655.

McKinnon, L., P. A. Smith, E. Nol, J. L. Martin, F. I. Doyle, K. F. Abraham, H. G. Gilchrist, R. I. G. Morrison, and J. Bêty (2010). Lower predation risk for migratory birds at high latitudes. Science 327:326-327.

Meltofte, H., T. Piersma, H. Boyd, B. McCaffery, B. Ganter, V. V. Golovnyuk, K. Graham, C. L. Gratto-Trevor, R. I. G. Morrison, E. Nol, H.-U. Rösner, D. Schamel, et al. (2007). Effects of climate variation on the breeding ecology of Arctic shorebirds. Meddelser om Grønland-Bioscience 59:1-48.

Myers, J. P. (1981). Cross-seasonal interactions in the evolution of sandpiper social systems. Behavioral Ecology and Sociobiology 8:195-202.

Nettleship, D. N. (1973). Breeding ecology of turnstones Arenaria interpres at Hazen Camp, Ellesmere Island, N.W.T. Ibis 115: 202-217.

Olson, V. A., A. Liker, R. P. Freckleton, and T. Székely (2008). Parental conflict in birds: Comparative analyses of offspring development, ecology and mating systems. Proceedings of the Royal Society of London, Series B 275:301-307.

Olson, V. A., T. J. Webb, R. P. Freckleton, and T. Székely (2009). Are parental care trade-offs in shorebirds driven by parental investment or sexual selection? Journal of Evolutionary Biology 22:672-682.

Otter, K. A., I. R. K. Stewart, P. K. McGregor, A. M. R. Terry, T. Dabelsteen, and T. Burke (2001). Extra-pair paternity among Great Tits Parus major following manipulation of male signals. Journal of Avian Biology 32:338-344.

Parmelee, D. F. (1970). Breeding behavior of the Sanderling in the Canadian High Arctic. Living Bird 9:97-146.

Parmelee, D. F., and R. B. Payne (1973). On multiple broods and the breeding strategy of Arctic Sanderlings. Ibis 115:218-226.

Pienkowski, M. W., and G. H. Green (1976). Breeding biology of Sanderlings in north-east Greenland. British Birds 60:165-177.

Piersma, T., J. van Gils, and P. Wiersma (1996). Family Scolopacidae (sandpipers, snipes and phalaropes). In Handbook of the Birds of the World, vol. 3 (del Hoyo, J. A. Elliott, and J. Sargatal, Editors). Lynx Edicions, Barcelona, Spain. pp. 444-533.

Pitelka, F. A., R. T. Holmes, and S. F. MacLean, Jr. (1974). Ecology and evolution of social organization in Arctic sandpipers. American Zoologist 14:185-204.

Reneerkens, J., A. Benhoussa, H. Boland, M. Collier, K. Grond, K. Günther, G. T. Hallgrimsson, J. Hansen, W. Meissner, B. de Meulenaer, Y. Ntiamoa-Baidu, T. Piersma, et al. (2009). Sanderlings using African-Eurasian flyways: A review of current knowledge. Wader Study Group Bulletin 116:2-20.

Reneerkens, J., and K. Grond (2009). Return rates, mate fidelity and territory size of Sanderlings Calidris alba in Zackenberg. In Zackenberg Ecological Research Operations, 14th Annual Report, 2008 (L. M. Jensen and M. Rasch, Editors). National Environmental Research Institute, Aarhus, Denmark. pp. 8991.

Reneerkens, J., K. Grond, H. Schekkerman, I. Tulp, and T. Piersma (2011). Do uniparental Sanderlings Calidris alba increase egg heat input to compensate for low nest attentiveness? PLoS ONE 6(2):e16834.

Reynolds, J. D. (1996). Animal breeding systems. Trends in Ecology \& Evolution 11:68-72.

Reynolds, J. D., and T. Székely (1997). The evolution of parental care in shorebirds: Life histories, ecology, and sexual selection. Behavioral Ecology 8:126-134.

Richardson, D. S., F. L. Jury, K. Blaakmeer, J. Komdeur, and T. Burke (2001). Parentage assignment and extra-group paternity in a cooperative breeder: The Seychelles Warbler (Acrocephalus sechellensis). Molecular Ecology 10:22632273.

Rousset, F. (2008). GENEPOP'007: A complete re-implementation of the GENEPOP software for Windows and Linux. Molecular Ecology Resources 8:103-106.

Sandercock, B. K., D. B. Lank, R. B. Lanctot, B. Kempenaers, and F. Cooke (2000). Ecological correlates of mate fidelity in two Arctic-breeding sandpipers. Canadian Journal of Zoology 78: 1948-1958.

Schamel, D., D. M. Tracy, D. B. Lank, and D. F. Westneat (2004). Mate guarding, copulation strategies and paternity in the sex-role reversed, socially polyandrous Red-necked Phalarope Phalaropus lobatus. Behavioral Ecology and Sociobiology 57: 110-118.

Schmidt, N. M., R. A. Ims, T. T. Høye, O. Gilg, L. H. Hansen, J. Hansen, M. Lund, E. Fuglei, M. C. Forchhammer, and B. Sittler (2012). Response of an Arctic predator guild to collapsing lemming cycles. Proceedings of the Royal Society of London, Series B 279:4417-4422.

Shuster, S. M., and M. J. Wade (2003). Mating Systems and Strategies. Princeton University Press, Princeton, NJ, USA.

Smith, P. A., H. G. Gilchrist, M. R. Forbes, J.-L. Martin, and K. Allard (2010). Inter-annual variation in the breeding chronology of Arctic shorebirds: Effects of weather, snow melt and predators. Journal of Avian Biology 41:292-304.

Smith, P. A., and S. D. Wilson (2010). Intraseasonal patterns in shorebird nest survival are related to nest age and defence behaviour. Oecologia 163:613-624.

Székely, T., R. P. Freckleton, and J. D. Reynolds (2004). Sexual selection explains Rensch's rule of size dimorphism in shorebirds. Proceedings of the National Academy of Sciences USA 101:12224-12227.

Székely, T., A. Kosztolanyi, C. Küpper, and G. H. Thomas (2007). Sexual conflict over parental care: A case study of shorebirds. Journal of Ornithology 148:S211-S217.

Székely, T., and J. D. Reynolds (1995). Evolutionary transitions in parental care in shorebirds. Proceedings of the Royal Society of London, Series B 262:57-64.

Székely, T., J. D. Reynolds, and J. Figuerola (2000). Sexual size dimorphism in shorebirds, gulls, and alcids: The influence of sexual and natural selection. Evolution 54:1404-1413.

Thomas, G. H., R. P. Freckleton, and T. Székely (2006). Comparative analyses of the influence of developmental mode on phenotypic diversification rates in shorebirds. Proceedings of the Royal Society of London, Series B 273: 1619-1624.

Thomas, G. H., and T. Székely (2005). Evolutionary pathways in shorebird breeding systems: Sexual conflict, parental care, and chick development. Evolution 59:2222-2230. 
Thomas, G. H., T. Székely, and J. D. Reynolds (2007). Sexual conflict and the evolution of breeding systems in shorebirds. Advances in the Study of Behavior 37:279-342.

Tökölyi, J., and Z. Barta (2011). Breeding phenology determines evolutionary transitions in migratory behaviour in finches and allies. Oikos 120:184-193.

Tomkovich, P. S., and M. Y. Soloviev (1994). Site fidelity in High Arctic breeding waders. Ostrich 65:174-180.

Tomkovich, P. S., and M. Y. Soloviev (2001). Social organization of Sanderlings breeding at northern Taimyr, Siberia. Ornithologia (Moscow) 29:125-136.
Tulp, I., and H. Schekkerman (2006). Time allocation between feeding and incubation in uniparental Arctic-breeding shorebirds: Energy reserves provide leeway in a tight schedule. Journal of Avian Biology 37:207-218.

Wallander, J., Blomqvist, D., and J. T. Lifjeld (2001). Genetic and social monogamy: Does it occur without mate guarding in the Ringed Plover? Ethology 107:561-572.

Whitfield, D. P., and P. S. Tomkovich (1996). Mating system and timing of breeding in Holarctic waders. Biological Journal of the Linnean Society 57:277-290. 